\title{
KEY TECHNOLOGIES FOR PREFABRICATED TIMBER BUILDINGS
}

\author{
Minjuan He*, Jing Luo*, Zheng Li* \\ * Tongji University, Dept. Civil Engineering, China \\ e-mails: hemj@tongji.edu.cn, 1610158@tongji.edu.cn, zhengli@tongji.edu.cn
}

\begin{abstract}
Nowadays, Chinese government has enacted a series of regulations and policies to increase the prefabrication level in building constructions. Timber structures are featured by the characteristic of a high level of prefabrication. A lot of attention has been paid on the research and application of prefabricated timber buildings recently. This paper presents a brief introduction of the structural systems and key technologies for prefabricated timber buildings. A few case studies on multi-story timber or timber-hybrid buildings are analysed with the emphasis on introducing their structural system and the respective construction techniques. The objective is to provide selected examples to explore the possible strategies with the understanding that prefabricated construction is an organizational process based on a steady flow of stages of the whole construction process. The current knowledge gaps are identified and discussed, concerning the industrialization process and an increasing degree of assembling. Furthermore, future opportunities for prefabricated timber buildings have been put forward.
\end{abstract}

Keywords: Timber structures, Multi-story buildings, Construction Technologies, Prefabrication.

\section{INTRODUCTION}

Prefabricated timber buildings, which is featured by prefabricated components and on-site installation have been promoted in recent years [1]. It brings about the transformation and updating of the construction structure as the industrialization process comes into a certain stage. China's urbanization rate is growing two to three times faster than ever before, from only $19 \%$ in 1979 to $53.73 \%$ in 2013 [2]. In the years that followed, the China's New-style Urbanization Plan (2014-2020) was released by the central government, with the determination and confidence that by 2020 the urbanization rate needs to reach $60 \%$ [3]. While the construction industry contributes significantly to the urbanization process, the rising labor costs in China is an unavoidable issue and have encouraged manufacturers to turn to automation. Therefore, there is a need to control and minimum in situ construction activity under strict quality to reduce the cost. Meanwhile, as fragile ecological environment, insufficient environmental capacity and shortage of resources are the key obstacles which stands in the way of the world's development, many new concepts of sustainable urban development are purposed recently. The construction industry should also strive hard to attain this goal. Since the prefabricated buildings system has many benefits, such as the constant quality surveillance and control [4], shorter construction time [5], environmentally friendly way of building, etc., it is an inevitable trend of social development to replace the conventional labor-intensive construction method.

To facilitate such a transition, Chinese government has enacted a series of regulations and policies, such as the State Council's guidance on the development of fabricated buildings (2016) [6], and the CCCPC's Opinions on Further Strengthening the Management of Urban Planning and Construction (2016) [7]. In coordination with related polices, new industrial standards and criterions have been implemented, such as Technical code for assembled steel structure buildings (GB/T51232-2016) [8], Technical code for prefabricated timber buildings (GB/T51233-2016) [9], Technical code for precast concrete buildings (GB/T51231-2016) [10]. 
This paper is intended to explore the key technologies of prefabricated timber buildings. Discussions around this topic have raise awareness in both researchers and designers. This paper discusses (1) the classification of the building structures and layout systems; (2) the related key technologies of prefabricated timber buildings; (3) some detailed case studies in engineering practice; and (4) the current knowledge gaps and future directions for prefabricated timber buildings.

\section{STRUCTURAL FORMS}

Wood, as a building material, is suitable for many structural applications. According to the different dimensions of engineered wood products. Wood can be used as the line elements or the panel elements in the load-bearing system. The wood line elements are often seen in post-and-beam construction; timber truss; and timber spatial structure, while the wood panel elements are common in wood frame construction and cross laminated timber structure. It can be combined with other engineering materials.

\subsection{Post-and-beam construction}

"Post-and-beam" allows more open floor space design and has many architectural merits, which is suitable for multi-stories residential buildings (Fig. 1). It consists of continuous floor-to-roof posts and horizontal beams to form a main frame structure. Detailing of the connection is particular important for this type of construction to ensure structural safety. It has been a common practice to connect posts to foundation by steel angles, sleeve footings or hold-downs, while beams are frequently pin connected [11]. As it can support effectively vertical loads but very low resistance to horizontal actions, the vertical bracing system [12], timber shear walls or continuous floor-to-roof cantilevered timber walls [13] [14] are also suitable in many applications.

\subsection{Timber truss}

Timber truss can be used as a great variety of roofs, with large spans and a high aesthetic quality (Fig. 2). There are several mechanical joints according to the different forms of trusses in each case. An ancient practice is to use carpentry joints to connect timber trusses of few members [15]. But for a larger span, mechanical joints with internal connection plates and bolts or fasteners are more practical, as they can provide greater load-resistance and better protection against fire. The optimization of timber truss can be achieved by programming in Matlab twenty-four elitist genetic algorithm models with different variables such as its geometry, the cross-section dimensions, and the number of dowels [16].

\subsection{Timber spatial structure}

Timber spatial structures (Fig. 3) can be divided into two categories: timber reticulated spatial structures and timber tensile structures [17]. The performance of timber spatial structures can be influenced by the type of load-carrying system, method of securing a structure against both local and global loss of stability, support types, as well as the type of joints. The analysis shows that connections made by means of steel plates, or steel elements perform better than traditional connections, in which timber elements are interconnected directly [18]. The major forms of connections are bolted joints with slotted-in steel plate, bonded rods joints [19], etc.

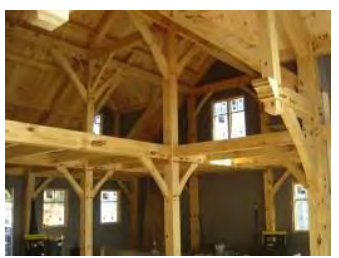

Fig.1. Post-and-beam construction.

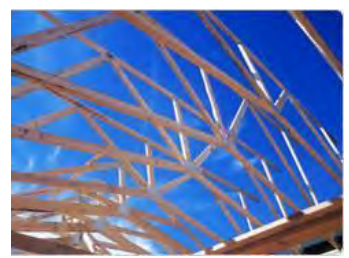

Fig.2. Timber truss.

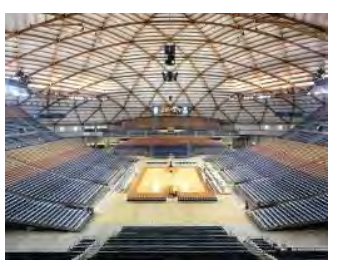

Fig.3. Timber spatial structure. 


\subsection{Wood frame construction}

Wood frame construction (Fig.4) is used in a large scale especially in USA, Canada and several European countries. The vertical shearwalls and horizontal diaphragms form an integral part of the load path. OSB board, plywood or varying chip-boards are connected to framing with nailing, screws or steel staples in order to sheath to one or both side of diaphragms [20]. Current direction of formation of the wood frame construction is the application of industrially component units, which guarantee high level of assembling and reliability of structural elements [21].

\subsection{Cross laminated timber structure}

CLT structures (Fig.5) are often characterized by the presence of shearwalls, which have been found effective in the matter of resisting lateral forces from earthquake or wind loads [22]. Therefore, it is an ideal structural form for Multi-stores building superstructures. Capacity design principles are used to design seismic resistance of CLT buildings. The connections provide the primary source of yielding while the panel still remains elastic. Long self-tapping screws, and traditional dowel-type fasteners such as wood screws, nails, lag screws, bolts and dowels are commonly used for connecting [23].

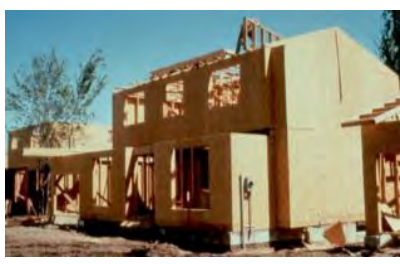

Fig.4. Wood frame construction.

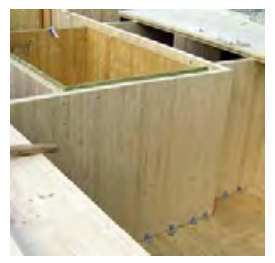

Fig.5. Cross laminated timber structure.

\subsection{Wood-hybrid building system}

Wood-hybrid building system is based on the integration of wood with other engineering materials, such as steel, concrete, or masonry etc. For timber and concrete hybrid structure, concrete frame and light frame wood diaphragm and roof system is widely used especially for multi-stories structure. Analysis shows that displacement lay between the rigid floor model and flexible model [24]. In high-rise building, combination types such as concrete core and glulam frame system are also recommended. Furthermore, the ground story can be cast in-situ reinforced concrete framing and the upper stories are assembled by CLT shear walls. For steel-timber hybrid-based construction system, there are different levels of collaboration between wood and steel. Steel frames and beams with cross-laminated timber panels system is one of the combination and shows good structural in-plane stability, as well as highly industrialized technology [25]. The research shows that Wood-hybrid building system perform good seismic behavior, fire resistance and structural reliability with reasonable structural design [26].

\section{KEY TECHNOLOGIES TO PROMOTE PREFABRICATED CONSTRUCTION}

Prefabricated construction is an organizational process based on a steady flow of stages of the whole construction process. It involves standardization and a high degree of organization of work [27]. There are several key technologies that should be taken into consideration in prefabricated construction.

\subsection{Selection of structure system}

The level of assembly has a close relationship with the structure form you select in the design phase. Under the limitations like the transportation, processing level etc., preparation and production are on the way to realize plans for buildings. Usually this process is called customer and supplier negotiations and early design to on-site assembly, which, as shown in the Fig.6, requires a considerable amount of time [28]. Software such as Building Information Modelling (BIM) can store the information of prefabricated units, and it is an essential tool in digital management proposition. 


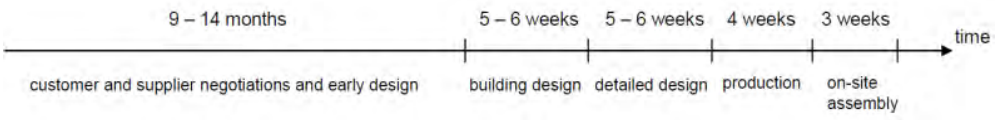

Fig. 6. Process phases on a time axis.

\subsection{Level of prefabrication}

For several decades, it has become a trend to reduce on-site construction and increase factory prefabrication. There are 4 main categories of Off-Site fabrication: component (or sub-assembly) systems, penalized systems, volumetric systems, and modular systems. For wood frame construction, as shown in Fig.7, consideration should be given to all the aspects such as the factory equipment, consignment conditions, and integration costs before the off-site fabrication [28]. In a highly industrialized world, with a high mechanization degree and high labor costs, element prefabrication and volume element prefabrication are probably better choices. Usually these elements contain built-in all installations, exterior and interior finishes, having installed doors and windows. For CLT structure, Since the CLT wall are assembled by a clear separation in layers for construction, insulation, installation and cladding, it enables different degrees of prefabrication at the factory. The material of the core can be either concrete cast in-situ or prefabricated CLT shear walls, depending on the capacity and rigidity requirements of the structure. And it also provides an easier execution of repair and alteration work at the facade, insulation and installation.

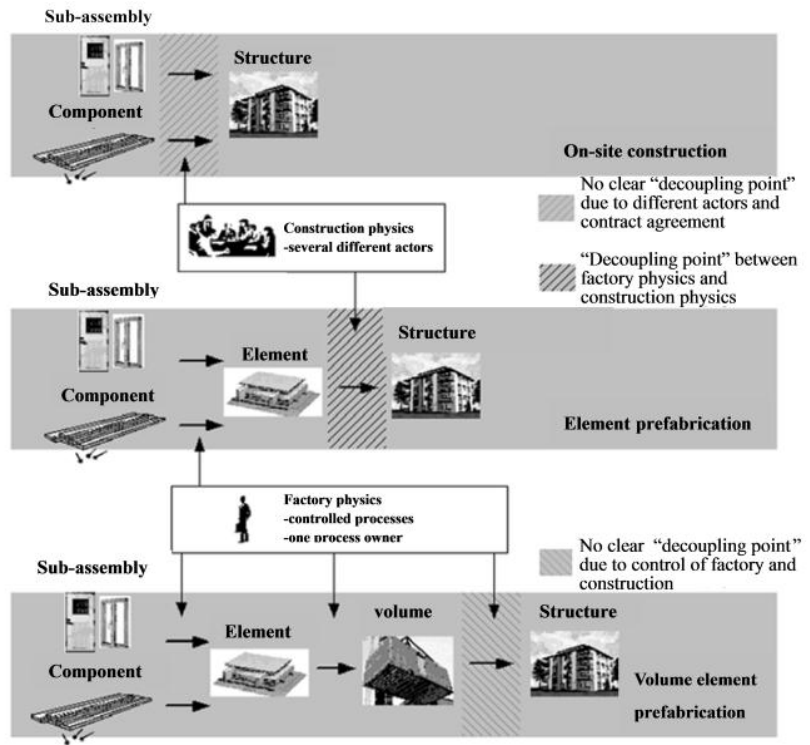

Fig. 7. Different level of prefabrication in wood frame construction.

\subsection{Standardization of engineered wood products}

A wide range of standard structural wood products plays an important part in assemble design. The main wood-based structural members include: dimension lumber, plywood, glulam, and CLT etc. [29]. It is necessary to redistribute and reinforce natural defects by forming the products into structurally efficient shapes. Therefore, the grading standard is a must. There are two types of strength grading: visual strength grading (VSG) and machine strength grading (MSG). 
However, the standardized lengths and dimensions of the materials are not comprehensive in China. For dimension lumber, material criteria such as the lumber species, lumber grades, moisture content, permitted cross-sectional deviations and the standard size etc. are defined according to the code for design of timber structures (GB50005-2017) [30], permitting a structural engineer to choose a given strength value from the class of timber in their design calculations. It is similar in glulam, the material criteria of which are defined in technical code of glued laminated timber structures (GB/T50708-2012) [31]. But the code only dictate that the thickness of lumber shall not exceed $45 \mathrm{~mm}$. the standard sizes are not given. Usually factory has its own product specifications or customized special specifications. For plywood, the regulation such as sheathing plywood for timber structures (GB/T22349--2008) [32] puts forward special requirements on the standard sizes and structural performance requirements for factory production and structural design.

For CLT, since it is a new kind of structural wood product developed decades ago, the standard requirements are not completed in Chinese code. CLT clearly offers a number of advantages, especially in terms of isotropy, high bearing capacity, a high dimensional stability in-plane and a high degree of prefabrication, in comparison to other timber products [33]. It is widely used in high-rise building projects in foreign country. More standard requirements of CLT are expected to promote the development of construction industrialization.

In European norms, there have a clear direction and standard requirements for the product properties. The standardized lengths and dimensions are defined by BS EN 336:2013 [34]. Product properties such as the section characteristics and specific strength classes are defined in coordination with related specifications, such as EN 14081 for solid construction timber; EN 14080 for glued-laminated timber; EN 14915 for wall and facade panelling made of solid wood and EN 15497 for Finger-jointed timber.

\subsection{Reliable connections in prefabricated timber structures}

A wide range of connections such as mechanical connections, adhesive connections, and carpentry connections, is required in timber structures [35]. Some highly-industrialized connections designed for multi-stores prefabricated modular buildings are also proposed in recent research [36]. Bolt joints provide a simple yet effective method of timber connection and is now widely available on engineering projects, but it has a low slip modulus. Prestress tube bolted connection (PTBC), a new innovative timber joint for timber structures was designed to solve this problem. The wood elements and other coupling components were all prefabricated in factory and installed as a complete unit. The steel tube was glued with a PVC tube, then they were inserted into timber holes and prestressed by a pretensioned bolt. Thus, it could resist the slip of steel plate by the friction between steel plate and tubes. Loading test was conducted, which indicated better performance over conventional bolt joints in terms of load-bearing capacity, slip modulus and ductility [37]. A series of parametric analysis was carried out in a three-dimensional finite element model established by finite element software ABAQUS. After changing the variables such as the pretension force of high strength bolt, the friction coefficient between steel tubes and steel plate, etc., the analysis was applied and showed good agreement with the test results (Fig. 8 and Fig.9) [38].

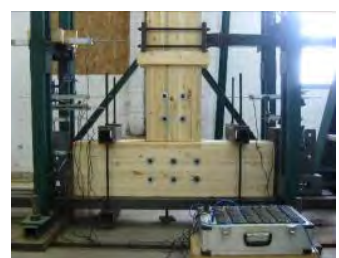

Fig. 8. Test setup.

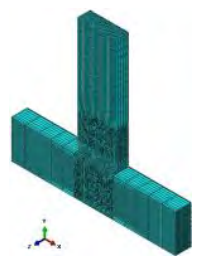

Fig. 9. A finite element model.

Another innovative idea was proposed by using the self-tapping screw as perpendicular reinforcement for the glulam beam-to-column connection (Fig. 10). The self-tapping screws were used to transmit the tensile stress perpendicular to grain and shear stress parallel to grain, thus, it could mitigate the 
propagation of fracture and improve the bearing capacity. Parameters analysis was applied by changing the diameter, spacing and number of self-tapping screws. Results showed that the increase of the number and diameter of self-tapping screws could improve the ultimate moment resistance, the failure rotation, the ductility and the total dissipated energy [39].

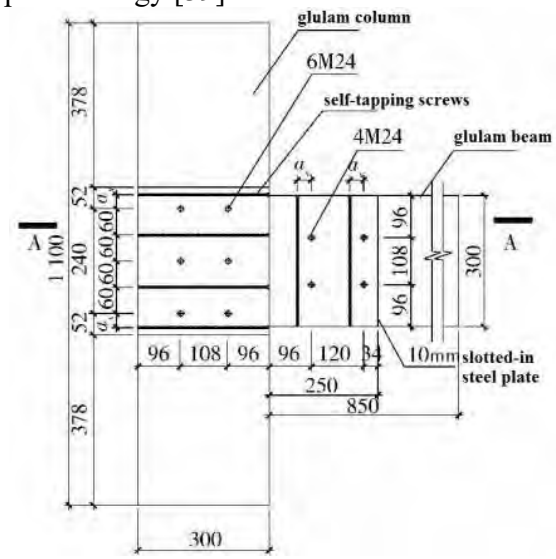

Fig. 10. Glulam beam-to-column connections enforced by self-tapping screws (STS).

\subsection{High integration of pipeline and built-in all installations}

A special technology line for prefabricated building can be shown in Fig.11. It is a typical timber volume prefabrication process in Sweden, which is also worthy to other countries. Firstly, Wood product, thermal insulation, sheathing and other metal fasteners are assembled horizontally into the basic elements. Then, place them in corresponding positions and assembly to volume modules by installing the built-in doors, windows and inside installation. The next step is to install all inside and outside finishes. Once finished, the completed module can be transported to the site [28].

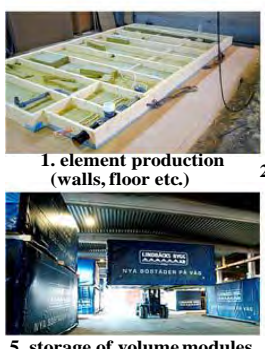

5. storage of volume modules

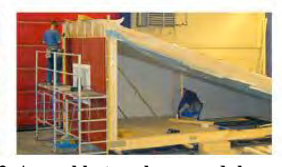

2. Assembly to volume modules

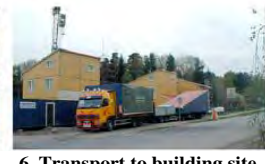

6. Transport to building site

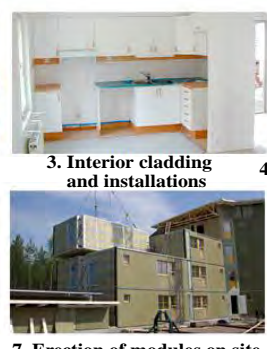

7. Erection of modules on site
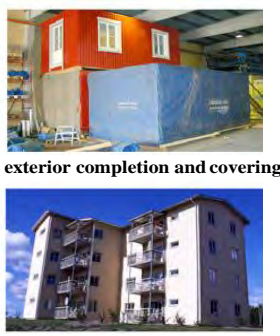

8. Finalized building

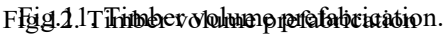

\section{CASES STUDIES}

\subsection{The Stadthaus, London}

The nine-storey Statdhaus apartment building in Murray Grove, London is the tallest residential building in the world at that time (Fig.12(a)). All vertical load-bearing and lateral resistance is provided by CLT walls and cores. Foundation are bored, cast in-situ reinforced concrete piles, and the ground story is also cast in-situ reinforced concrete framing [40]. Each of the panels is prefabricated, with the reserved cut-outs for windows and doors in factory, which dramatically reduced the time on site when all the elements were craned into position. Platform construction is another characteristic of the assembly. It 
allows a relatively repetitive and safe operation. As shown in Fig.12(b), the order of installation is to install the stairwell and elevator shaft first, since it can provide lateral stiff of the structure, followed by the CLT walls all around. Therefore, each of the nine floors was completed in 3 days. The entire overall construction time was 49 weeks [41].

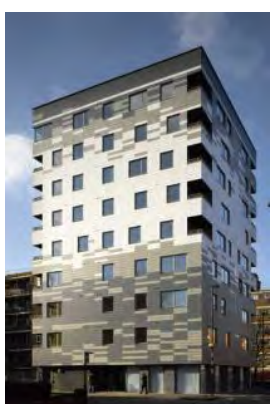

(a)

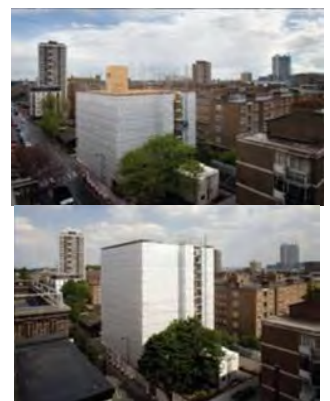

(b)

Fig.12. The Stadthaus, London.

(a) A 3D-view of the building; (b) Construction process

\section{2 "Treet", Norway}

Treet is a 14-stores timber residential building, located in the city of Bergen, Norway (Fig.13(a)). The global stiffness of the building is provided by the glulam trusses. A covering material made of glass and metal sheeting is used to protect the timber structure from sun and rain. Prefabricated building modules, found on levels $1-4,5,6-9,10$ and 11-14, are stacked on top of the concrete garage and strengthened level. The construction process of the building reflects a high level of prefabrication. The logistics and installation procedures are clear, as shown in Fig. 13(b). The foundation and garage level are constructed by concrete. The glulam frames are prefabricated in factory as large as possible under the transportation limit. The first 4-level prefabricated module is installed on the top of the garage. Then, the glulam frames are lifted in-between the modules and connected by dowels and slotted-in steel plates. The modules are lifted and installed into the strengthened level, covered with a concrete desk. The next two steps is the repeated assembly process of the previous step using the concrete desk as the foundation [42].

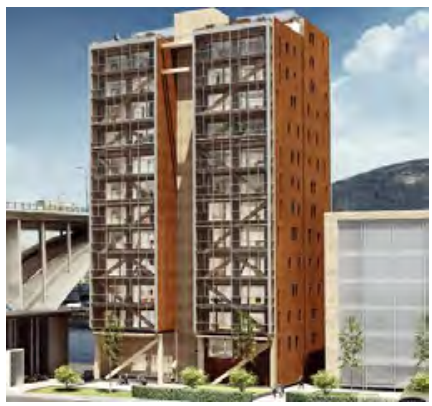

(a)

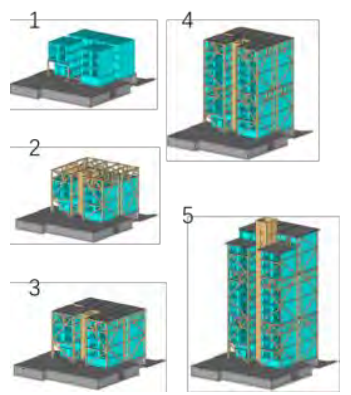

(b)

Fig.13. "Treet", Norway.

(a) A 3D-view of the building; (b) Construction process 


\subsection{UBC Tall Wood Building, Canada}

The 18-storey UBC Tall Wood Building is a hybrid structure system (Fig.14). With a physical height of $53 \mathrm{~m}$, the 17 -storey mass wood construction is proceeded above the first storey made of concrete. The foundations, ground floor and the building cores are cast-in-place concrete also to allay concerns about seismic safety. The mass-timber columns are made of standard Glulam with some parallel strand lumber columns on the lower levels for increased compression strength. The floors are made of CLT. The construction project lasted 593 days and completed in May 2017. The concrete cores are erected prior to the mass timber structure to provide lateral stiff of the structure. All connections are easy to assembly, which allows a high level of precision. A steel ledger angle can connect the CLT panels to the cores, with the consideration of eliminating the differential settlement between CLT panels and the cores. The drag strap to core connection can transfer any lateral loads on the building to the cores, and thus, the CLT panels and the cores form into an integral structure. Another innovative connection is the connection between columns and panels that can not only transfer the vertical loads but also the panel shear loads [43].

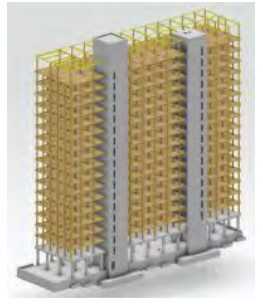

(a)

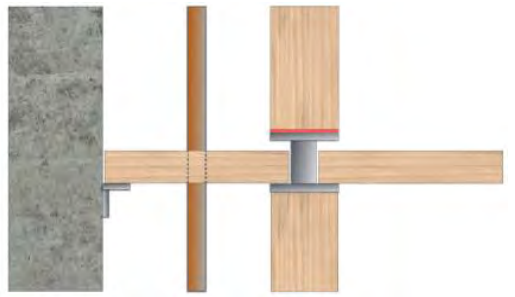

(b)

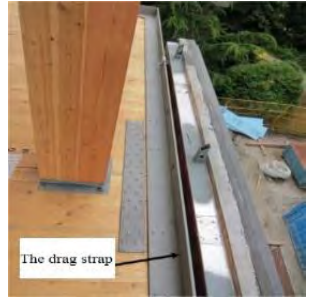

(c)

Fig.14. UBC Tall Wood Building.

(a) A 3D-view of the building; (b) The steel ledger angle connection between core and CLT floor;

(c) The drag strap to core connection;

\section{FUTURE OPPORTUNITIES AND PROSPECTS}

Prefabricated timber buildings have been represented as the current direction of the construction industry. The future opportunities and prospects are described as follows:

The basic requirement of modern prefabricated timber building is the development of engineered wood products. With the high-rise building getting popular in the late19th century, the impact of wood' drawbacks will gradually emerge [44]. All these affect the quality of prefabricated timber buildings. And currently, Engineers and technicians have been adept in past decades at advancing the manufacturing system to develop stronger and more fire-resistant engineered wood products. A key innovation is known as CLT. It provides a high level of dimensional stability, which allows for prefabrication of long floors, tall plates, etc.

The focus of solid timber construction will be the research and development of the standardization system comprising adequate connections, wood components systems for economic assembling and prefabricated systems for various structures, both in theory and in practice. A precise modern management system and strict quality control system are the prerequisites for standardization.

In addition, codes and regulations should be published to broaden the fields of application for prefabricated wood products. Government, university, and private scientists are now developed a series of pilot projects and relevant tests to raise the level of quality and efficiency of the prefabricated timber buildings even higher. And they will achieve widespread public adoption covering not only residential houses but also commercial and public facilities. 


\section{ACKNOWLEDGEMENT}

The authors gratefully acknowledge National Key R\&D Program of China (Grant No. 2016YFC0701603) for supporting this research.

\section{REFERENCES}

[1] Nawi M.N.M., Lee A., Nor K.M, "Barriers to Implementation of the Industrialised Building System (IBS) in Malaysia”, Built \& Human Environment Review, 4:22-35, 2011.

[2] Mingxing C., "Evolution and assessment on China's urbanization 1960-2010: underurbanization or over-urbanization?", Habitat International, 38(38):25-33, 2013.

[3] NDRC (National Development and Reform Commission), "China's new-style urbanization plan (2014-2020)", Available from: http://news.xinhuanet.com/politics/201403/16/c_119791251.htm (2014-03-16).

[4] Nawi M.N.M., Nifa, F.A.A., Musa, S., Sudirman, M.D., "A Preliminary Survey of the Application of IBS in Malaysian Construction Industry: Barriers to implement in Kedah and Perlis", Proceeding in Conference ITB, Indonesia, 2007.

[5] Thanoon, W.A.M., Peng, L.W., Kadir, M.R.A., Jaafar, M.S., Salit, M. S., "The Essential Characteristics of Industrialized Building System", Proceeding of International Conference Industrialized building systems, Malaysia,2003.

[6] General Office of the State Council, "the State Council's guidance on the development of fabricated buildings", Available from: http://www.gov.cn/zhengce/content/201609/30/content_5114118.htm (2016-09-30).

[7] CPC Central Committee, The State Council. "the CCCPC's Opinions on Further Strengthening the Management of Urban Planning and Construction", Available from: http://www.gov.cn/gongbao/content/2016/content_5051277.htm (2016-02-06).

[8] The Ministry of Housing and Urban-Rural Development of China, "GB/T51232-2016 Technical code for assembled steel structure building", Beijing: China Building Industry Press, 2016.

[9] The Ministry of Housing and Urban-Rural Development of China, "GB/T51233-2016 Technical code for prefabricated timber buildings", Beijing: China Building Industry Press, 2016.

[10] The Ministry of Housing and Urban-Rural Development of China, "GB/T51231-2016 Technical code for precast concrete buildings", Beijing: China Building Industry Press, 2016.

[11] Gattesco N., Boem I., "Seismic performances and behavior factor of post-and-beam timber buildings braced with nailed shear walls", Engineering Structures, 100:674-685, 2015.

[12] Popovski M., Karacabeyli E., "Force modification factors and capacity design procedures for braced timber frames", 14th World Conference on Earthquake Engineering, China, 2008.

[13] Buchanan A., Deam B., Fragiacomo M., et al., "Multi-Storey Prestressed Timber Buildings in New Zealand", Structural Engineering International, 18(2):166-173, 2008.

[14] Parida G., Fragiacomo M., Johnsson H., "Prefabricated timber walls anchored with glued-in rod connections: racking tests and preliminary design", European Journal of Wood \& Wood Products, 71(5):635-646, 2013.

[15] Villar J. R., Guaita M,. Vidal P., et al., "Numerical simulation of framed joints in sawn-timber roof trusses", 6(4):508-520, 2008.

[16] Villar J. R., Vidal P., Fernández M. S., et al., "Genetic algorithm optimisation of heavy timber trusses with dowel joints according to Eurocode 5", Biosystems Engineering, 144:115-132, 2016. 
[17] Minjuan H., Hanlin D., Zheng L., "State-of-the-art and key research topics of timber spatial structures", Building Structure, 12:103-109, 2016 (in Chinese).

[18] Straka B., "Conclusions from Theoretical Analysis, Construction and Behavior of Timber Spatial Structures", Proceedings of the 6th World Conference on Timber Engineering, Canada, 2000.

[19] Harris R., Gusinde B., Roynon J., "Design and construction of the pods sports academy, Scunthorpe, England", World Conference of Timber Engineering, Auckland, 2012.

[20] Donald B., Kelly C., Kenneth F., David Pollock Jr., "Design of Wood Structures - ASD/LRFD (7th Edition)", New York: McGraw-Hill Education, 2014.

[21] Jarosław M., Czesław M., "Current Directions in Development of Modern Wood-framed Houses", Procedia Engineering, 2017, 172:701-705.

[22] Polastri A., Pozza L., Smith I., "Structural characterization of multi-storey CLT buildings braced with cores and additional shear walls", International Network on Timber Engineering Research, UK, 2015.

[23] Erol K., Brad D, et al., "CLT Handbook: cross-laminated timber(U.S. Edition)”, FPInnovations, 2013.

[24] Minjuan H., Shuo L., Suyi G., Chun N., "The Seismic Performance in Diaphragm Plane of Multi-Storey Timber and Concrete Hybrid Structure", Procedia Engineering, 14:1606-1612, 2011.

[25] Loss C., Piazza M., Zandonini R., "Connections for steel-timber hybrid prefabricated buildings. Part II: Innovative modular structures”, Construction \& Building Materials, 122:796-808, 2015.

[26] Minjuan H., Duo T., Zheng L., "State-of-the-art of research advances on multi-story timber and timber-hybrid structures", Journal of Building Structures, 37(10): 1-9 , 2016 (in Chinese).

[27] Hassim S., Jaafar M.S., Sazalli S.A.A.H., "The contractor perception towers Industrialised Building System risk in construction projects in Malaysia", American Journal of Applied Sciences, 6 (5): 937-942, 2009.

[28] Sandberg M., Johnsson H., Larsson T., "Knowledge-based engineering in construction: The prefabricated timber housing case", Electronic Journal of Information Technology in Construction, 13:408-420, 2008.

[29] Ramage M. H., Burridge H., Busse-Wicher M., et al., "The wood from the trees: The use of timber in construction”, Renewable \& Sustainable Energy Reviews, 68(1):333-359, 2017.

[30] The Ministry of Housing and Urban-Rural Development of China, "GB50005-2017 Code for design of timber structures", Beijing: China Building Industry Press, 2017.

[31] The Ministry of Housing and Urban-Rural Development of China, "GB/T50708-2012 Technical code of glued laminated timber structures”, Beijing: China Building Industry Press, 2012.

[32] China's General Administration of Quality Supervision, Inspection and Quarantine, "GB/T 22349--2008 Sheathing plywood for timber structures", Beijing: China Building Industry Press. 2008.

[33] Brandner R., Flatscher G., Ringhofer A., et al., "Cross laminated timber (CLT): overview and development", European Journal of Wood \& Wood Products, 74(3):1-21, 2016.

[34] The Standards Policy and Strategy Committee, "BS EN 336:2013 Structural timber-Sizes, permitted deviations", The British Standards institution, 2013.

[35] Mettem C. J., Bainbridge R. J., "A review of moment-resistant structural timber connections", Structures \& Buildings, 128(4):323-331, 1998. 
[36] Piazza M., Zandonini R., "Connections for steel-timber hybrid prefabricated buildings. Part II: Innovative modular structures”, Construction \& Building Materials, 122:796-808, 2016.

[37] Minjuan H., Shuna N., Renle M., Xue B., "Loading tests of prestressed tube bolted joint with slotted-in steel plate”, Journal of Tongji University (Social Science Section), 41(9):1353-1358, 2013 (in Chinese).

[38] Yi Z., Minjuan H., Renle M., "Bending bearing capacity and parametric analysis of prestressed tube bolted timber connections", Journal of Building Structures, 37(10):18-26, 2016 (in Chinese).

[39] Huifen L., Minjuan H., "Effects of self-tapping screw on performance of glulam beam-tocolumn connections", Journal of Building Structures, 36(7):148-156, 2015 (in Chinese).

[40] Wells M., "Stadthaus, London: Raising the bar for timber buildings", Proceedings of the Institution of Civil Engineers Civil Engineering, 2011, 164(3):122-128.

[41] Waugh A., Wells M., Lindegar M., "Tall Timber Buildings: Application of Solid Timber Constructions in Multi-Storey Buildings", CTBUH Journal, Issue I:24-27, 2011.

[42] Abrahamsen R. B., Malo K. A., "Structural design and assembly of "treet" - a 14-story timber residential building in Norway", World Conference on Timber Engineering, Canada, 2014.

[43] Poirier E., Moudgil M., Fallahi A., Staub-French S., Tannert T., "Design and construction of a 53-meter-tall timber building at the university of British Columbia", Proceedings of WCTE, Australia, 2016.

[44] Cornwall W., “Tall timber”, Science, 353(6306):1354-1356, 2016. 